\title{
Factors Affecting Farm Income of Small Dairy Farmers in Kandi and Plain Regions
}

\author{
Parteek Singh", H.K. Verma, S.S Dhindsa and R. Kasrija \\ Department of Veterinary and Animal Husbandry Extension Education \\ Guru Angad Dev Veterinary \& Animal Sciences University, Ludhiana, Punjab-141004, India \\ *Corresponding author
}

\section{A B S T R A C T}

\section{Keywords}

Socio-personal characteristics, Small dairy farmers, Farm income, Agro climatic zones

\section{Article Info}

Accepted:

04 August 2019

Available Online:

10 September 2019
Livestock sector plays important role in Indian economy. The dairy industry can go a long way in augmenting the income of the farmers. The present paper focuses on the factors affecting farm income. The study was conducted in the two agroclimatic zones of Punjab state i.e. kandi and plain zone. From each zone two districts, one block from each district and further three villages from each block and fifteen farmers from each village were selected randomly. The data was collected with personal interview method. The annual income realized by farmers varied a lot in both the regions. In kandi area agriculture and dairy was almost equal contributor to farm income. Whereas, agriculture was major contributor to total farm income in the plain region. Extension contacts were positively and significantly correlated with income from dairy and agriculture in the kandi region. Operational land holdings and mass media exposure were positively and significantly correlated with income from agriculture in plain region. It is suggested that there is an urgent need to strengthen veterinary extension services in the state. Further mass media should be used more to create awareness among the masses regarding dairy farming.

\section{Introduction}

Livestock sector plays important role in Indian economy as contribution of livestock sector in total GDP is 4.5 per cent and to agriculture GDP it is 26.1 per cent and from this 18 per cent is from dairy sector alone (National Accounts Statistics-2016; Central Statistical Organization, Govt. of India). The marginal and small farmers account for nearly 80 per cent of the total operational holding in the country. As per agriculture census 2012 there is total 10.58 lakh farming families in the state out of this 34 per cent are marginal and small farmers. Dairying has become an important secondary source of income for millions of rural families. It's often said that small farms are not viable at their own even if farmers get the best crop seeds and other inputs to cultivate combination of crops, the return will remain meager. The dairy industry can go a long way in augmenting the regular income of the farmers besides providing an impetus to the milk production in the state and the 
country. The present paper focuses on the factors affecting farm income (dairy + agriculture). The data were collected through personal interview method with the help of a structured schedule.

\section{Materials and Methods}

The study was conducted in the two agroclimatic zones of Punjab state i.e. kandi and plain zone. Two districts namely Hoshiarpur and Shaheed Bhagat Singh Nagar from kandi and Ludhiana and Sangrur from plain zone were selected. One block from each district and further three villages from each block were selected randomly. From each village 15 respondents owning less than five dairy animals were selected randomly, thus, totaling the sample size to 180 . The data were collected through personal interview method with the help of a structured schedule. The statistical tools like frequency, average, cumulative cube root method, mean score, correlation coefficients etc were used.

\section{Results and Discussion}

\section{Socio-personal characteristics of small dairy farmers}

In the kandi region nearly one third of the respondents were equally distributed in the three categories i.e. young, middle and old, whereas in plain region little less than half of the respondents were young i.e. up to 40 years of age and 31.11 per cent were in middle age category. It was found that 41.11 and 27.78 per cent were matriculate from the kandi and plain region, respectively. Majority of the respondents from both the regions belonged to the nuclear families and had upto five family members.

Majority of respondents 76.67 per cent from plain region were dependent on agriculture + dairy as compared to kandi region where farmers along these two, they also had service and business as their family occupation. One third of the respondents 33.33 per cent from the kandi area belong to small operational land holdings whereas nearly half of the respondents 47.78 per cent from plain region had medium operational land holdings.

Majority of respondents 70 per cent or more had less mass media exposure in both areas. Extension contacts were more in kandi region as compared to plain region.

\section{Income from agriculture and dairy}

The annual income realized by farmers varied a lot in both the regions. In kandi region, it varied from Rs.38,600/- to 87,800/- and above, whereas in plain region it ranged from Rs.60,000/- to 7,47,000/- and above. Average annual farm income in plain region was Rs 85337.15 whereas, it was Rs 5,77481.10 (Table 2).

Further it was analysed that how much dairy and agriculture are contributing to farm income. The data is presented in table 3. In kandi area, agriculture and dairy are almost equal contributor to farm income. Whereas, agriculture contribution 91.54 per cent to total farm income in the plain region.

\section{Area under fodder}

The data set in table 4 reveals that 47.78 per cent of the respondents from kandi region had area under fodder $<0.25$ acres, whereas only 6.67 per cent of respondents fell in this category from plain region. A little less than two third of the respondents from plain region had area under fodder from 0.25 to $<0.50$ acres and One third of the respondents from the kandi region fell in this category. Nearly one third of the respondents from the plain region and 18.89 per cent from kandi region have area under fodder from half an acre to one acre. 
Table.1 Distribution of respondents according to their socio-personal characteristics

\begin{tabular}{|c|c|c|c|c|c|}
\hline \multirow[t]{2}{*}{ Sr. No. } & \multirow[t]{2}{*}{ Socio-personal Characteristics } & \multicolumn{2}{|c|}{ Kandi $\left(n_{1}=90\right)$} & \multicolumn{2}{|c|}{ Plain $\left(\mathbf{n}_{2}=90\right)$} \\
\hline & & f & $\%$ & f & $\%$ \\
\hline \multirow[t]{4}{*}{1.} & \multicolumn{5}{|l|}{ Age } \\
\hline & Young (Up to $40 \mathrm{yrs}$ ) & 27 & 31.00 & 43 & 47.78 \\
\hline & Midle 40 to 54 yrs) & 31 & 34.44 & 28 & 31.11 \\
\hline & Old (54 yrs and above) & 32 & 35.56 & 19 & 21.11 \\
\hline \multirow[t]{6}{*}{2.} & \multicolumn{5}{|l|}{ Education level } \\
\hline & Primary & 18 & 20.00 & 13 & 14.44 \\
\hline & Middle & 10 & 11.11 & 10 & 11.11 \\
\hline & Matric & 37 & 41.11 & 25 & 27.78 \\
\hline & Sen. Secondary & 15 & 16.67 & 27 & 30.00 \\
\hline & Grad \& Above & 10 & 11.11 & 15 & 16.67 \\
\hline \multirow[t]{3}{*}{3.} & \multicolumn{5}{|l|}{ Type of family } \\
\hline & Joint & 23 & 25.56 & 22 & 24.44 \\
\hline & Nuclear & 67 & 74.44 & 68 & 75.56 \\
\hline \multirow[t]{3}{*}{4.} & \multicolumn{5}{|l|}{ Family size } \\
\hline & Upto 5 members & 67 & 74.44 & 62 & 68.89 \\
\hline & More than 5 to 8 members & 23 & 25.56 & 28 & 31.11 \\
\hline \multirow[t]{4}{*}{5.} & \multicolumn{5}{|l|}{ Family occupation } \\
\hline & Agriculture + Dairy & 24 & 26.67 & 69 & 76.67 \\
\hline & Agriculture + Dairy+Service & 38 & 42.22 & 3 & 3.33 \\
\hline & Agriculture + Dairy+Business & 28 & 31.11 & 11 & 12.22 \\
\hline \multirow[t]{6}{*}{6.} & \multicolumn{5}{|l|}{ Operational land holding } \\
\hline & Marginal (<1 ha) & 22 & 24.44 & 11 & 12.22 \\
\hline & Small (1-2 ha) & 30 & 33.33 & 9 & 10.00 \\
\hline & Semi-medium (2-4 ha) & 23 & 25.56 & 20 & 22.22 \\
\hline & Medium (4-10 ha) & 15 & 16.67 & 43 & 47.78 \\
\hline & Large (> 10 ha $)$ & 0 & 0.00 & 7 & 7.78 \\
\hline \multirow[t]{4}{*}{7.} & \multicolumn{5}{|l|}{ Mass media exposure } \\
\hline & Below 2 & 63 & 70.00 & 66 & 73.33 \\
\hline & 2 to $<4$ & 25 & 27.78 & 16 & 17.78 \\
\hline & 4 and above & 2 & 2.22 & 8 & 8.89 \\
\hline \multirow[t]{3}{*}{8.} & \multicolumn{5}{|l|}{ Extension contacts } \\
\hline & Below 5 & 45 & 50.00 & 67 & 74.44 \\
\hline & Above 5 & 45 & 50.00 & 23 & 25.56 \\
\hline \multirow[t]{4}{*}{9.} & \multicolumn{5}{|l|}{ Social participation } \\
\hline & No participation & 75 & 83.33 & 19 & 21.11 \\
\hline & 1 to 3 & 11 & 12.22 & 70 & 77.78 \\
\hline & 4 and above & 4 & 4.44 & 1 & 1.11 \\
\hline
\end{tabular}


Table.2 Distribution of respondents according to their annual farm income

\begin{tabular}{|c|c|c|c|c|}
\hline S.No & Annual farm Income (Rs) & $\mathbf{f}$ & $\%$ contribution & $\begin{array}{l}\text { Average annual } \\
\text { farm income (Rs) }\end{array}$ \\
\hline \multirow[t]{4}{*}{ A. } & \multicolumn{4}{|l|}{ Kandi $\left(\mathrm{n}_{1}=90\right)$} \\
\hline & 38600 to 58600 & 33 & 36.67 & \multirow[t]{3}{*}{85337.15} \\
\hline & 58600 to 87800 & 34 & 37.78 & \\
\hline & 87800 and above & 23 & 25.56 & \\
\hline \multirow[t]{4}{*}{ B. } & \multicolumn{4}{|l|}{ Plain $\left(\mathbf{n}_{2}=90\right)$} \\
\hline & 60000 to 355200 & 39 & 43.33 & \multirow[t]{3}{*}{577481.10} \\
\hline & 355200 to 747000 & 27 & 30.00 & \\
\hline & 747000 and above & 24 & 26.67 & \\
\hline
\end{tabular}

Table.3 Contribution of Agriculture and Dairy to total farm income of the respondents

\begin{tabular}{|l|c|c|c|c|}
\hline \multirow{2}{*}{$\begin{array}{l}\text { Average Annual farm } \\
\text { Income }\end{array}$} & \multicolumn{2}{|c|}{ Kandi } & \multicolumn{2}{c|}{ Plain } \\
\cline { 2 - 5 } & Rs. & \% contribution & Rs. & \% contribution \\
\hline Agriculture & 43388.889 & 50.84 & 528634.83 & 91.54 \\
\hline Dairy & 41948.267 & 49.16 & 54720.00 & 9.48 \\
\hline $\begin{array}{l}\text { Total average annual } \\
\text { farm income }\end{array}$ & 85337.156 & 100.00 & 577481.11 & 100.00 \\
\hline
\end{tabular}

Table.4 Distribution of respondents according to area under fodder

\begin{tabular}{|c|l|c|c|c|c|}
\hline Sr. No. & \multicolumn{1}{|c|}{ Management aspects } & \multicolumn{2}{c|}{$\begin{array}{c}\text { Kandi } \\
\left(\mathbf{n}_{1}=90\right)\end{array}$} & \multicolumn{2}{c|}{$\begin{array}{c}\text { Plain } \\
\left(\mathbf{n}_{2}=90\right)\end{array}$} \\
\cline { 3 - 7 } & \multicolumn{2}{|c|}{$\mathbf{f}$} & $\%$ & f & \% \\
\hline \multirow{2}{*}{1.} & Area under fodder (acres) & 43 & 47.78 & 6 & 6.67 \\
\cline { 2 - 7 } & $<0.25$ & 30 & 33.33 & 58 & 64.44 \\
\cline { 2 - 7 } & 0.25 to $<0.50$ & 17 & 18.89 & 26 & 28.89 \\
\hline
\end{tabular}


Table.5 Relationship of selected socio-personal characteristics with income of respondents

\begin{tabular}{|c|l|c|c|c|c|}
\hline \multirow{2}{*}{ Sr. No. } & \multirow{2}{*}{ Socio-personal characteristics } & \multicolumn{4}{|c|}{ Income } \\
\cline { 3 - 6 } & & \multicolumn{2}{|c|}{ Dairy } & \multicolumn{2}{c|}{ Agriculture } \\
\cline { 3 - 6 } & & Kandi & Plain & Kandi & Plain \\
\hline $\mathbf{1 .}$ & Education & -0.08 & 0.13 & 0.06 & 0.14 \\
\hline $\mathbf{2 .}$ & Extension contacts & $0.37 *$ & -0.07 & $0.52^{*}$ & 0.16 \\
\hline $\mathbf{3 .}$ & Mass media exposure & -0.15 & 0.05 & -0.13 & $0.25^{* *}$ \\
\hline $\mathbf{4 .}$ & Operational land holding & 0.15 & 0.14 & $0.96^{*}$ & $0.87^{*}$ \\
\hline $\mathbf{5 .}$ & Area under fodder & $0.37 *$ & $0.51^{*}$ & 0.11 & 0.15 \\
\hline $\mathbf{6 .}$ & No.of milch animals & $0.92^{*}$ & $0.96^{*}$ & $0.20^{* *}$ & $0.17^{*}$ \\
\hline $\mathbf{7 .}$ & Total no.of animals & $0.70^{*}$ & $0.58^{*}$ & -0.04 & $0.23^{* *}$ \\
\hline
\end{tabular}

*Significant at $1 \%$ level

$* *$ Significant at $5 \%$ level

Factors affecting performance of dairy farming

Performance of dairy farming was studied by working out the relationship of selected characteristics with the income realized by the respondents. Simple linear correlation was worked out and the data is represented in table 5 for kandi and plain regions. A perusal of the figures in table 5 reveals that extension contacts were positively and significantly correlated with income from dairy and agriculture in the kandi region. Non significant and very weak relationship was observed between extension contacts and income from dairy and agriculture in plain region. It may be due to the reason that in plain region majority fell in in the lower category of extension contacts (Table 1).

Operational land holding and mass media exposure was positively and significantly correlated with income from agriculture in plain region. Number of milch animals and total number of animals was positively and significantly correlated with average milk yield and income from dairy and agriculture in both regions. Area under fodder had no significant relationship with income from agriculture in both the regions, however it was positively and significantly correlated with income from dairy in both the region. It implies that availability of green fodder enhances milk yield hence income from dairy.

Extension contacts of dairy farmers are helpful in increasing the income from dairy and agriculture, in kandi region. Larger operational land holding of dairy farmers in both region also seems to increase the income from agriculture. It is also evident that by increasing the area under fodder crops, number of milch animal and total number of animals, income from dairy can be augumented in kandi as well as in plain region.

It can be concluded that in kandi region respondents were equally distributed in the three categories i.e. young, middle and old, whereas, in plain region little less than half of the respondents were young and respondents from both the regions belonged to the nuclear families and had upto five family members. Majority of respondents $(76.67 \%)$ from plain region were dependent on agriculture + dairy 
as compared to kandi region where farmers alongwith these two, they also had service and business as their family occupation. One third of the respondents $(33.33 \%)$ from the kandi area belong to small operational land holdings whereas nearly half of the respondents (47.78\%) from plain region had medium operational land holdings. Majority of respondents (70\% or more) had less mass media exposure in both areas. Extension contacts were more in kandi region as compared to plain region. The annual income realized by farmers varied a lot in both the regions. In kandi area agriculture and dairy were almost equal contributor to farm income, however, agriculture was major contributor to total farm income in the plain region. Extension contacts were positively and significantly $(\mathrm{P}<0.01)$ correlated with income from dairy and agriculture in the kandi region. Operational land holding and mass media exposure were positively and significantly correlated with income from agriculture in plain region. Area under fodder, number of milch animals and total number of animals was positively and significantly correlated with income from dairy and agriculture in both the regions except area under fodder had no significant relationship with income from agriculture in both the regions. It is suggested that there is an urgent need to strengthen veterinary extension services in the state for enhancing the transfer of available technologies to small dairy farmers. It is equally important to increase the availability of veterinarian in rural area by filling up their vacant posts. It is further suggested that mass media should be used more to create awareness among the masses regarding dairy farming.

\section{References}

Anonymous $2016 \quad$ www.indiastat.com retrieved on $04 / 08 / 2019$

Delgado, C. L., Narrod, C. A., and Tiongco, M. M., 2003. Project on livestock industrialization, trade and socialhealth-environment impacts in developing countries. FAO Corporate Document Repository.

Dev, K.,2014. Study on the feeding practices followed by dairy farmers in different agro-climatic zones of Punjab. M.V.Sc. thesis, Guru Angad Dev Veterinary \& Animal Sciences University, Ludhiana.

Kashish and V. Dhawan,2015. Socio economic profile of dairy farmers in Punjab: A case study of Amritsar district. International Journal of Multidisciplinary Approach and Studies 02 2: 155-62.

Kaur, M., 2001. Performance and problems of milk producer's cooperative societies of Milkfed in Punjab. M.Sc. thesis, Punjab Agricultural University, Ludhiana.

Nigam, S., and S. Kumar, 2008. "Contribution of livestock in Indian Scenario", Agricultural Situation in India 66(1): 25-28.

\section{How to cite this article:}

Parteek Singh, H.K. Verma, S.S. Dhindsa and Kasrija, R. 2019. Factors Affecting Farm Income of Small Dairy Farmers in Kandi and Plain Regions. Int.J.Curr.Microbiol.App.Sci. 8(09): 533538. doi: https://doi.org/10.20546/ijcmas.2019.809.064 